Research Report No. 20/2007

\title{
Reflexive Governance and European Company Law
}

Simon Deakin

Follow this and additional works at: http://digitalcommons.osgoode.yorku.ca/clpe

\section{Recommended Citation}

Deakin, Simon, "Reflexive Governance and European Company Law" (2007). Comparative Research in Law \& Political Economy. Research Paper No. 20/2007.

http://digitalcommons.osgoode.yorku.ca/clpe/237 


\section{Comparative Research in Law \& Political Economy}

\section{Simon Deakin}

Reflexive Governance and European Company Law

Paper for presentation at the Irish European Law Forum, January 2007

EDITORS: Peer Zumbansen (Osgoode Hall Law School, Toronto, Director, Comparative Research in Law and Political Economy, York University), J ohn W. Cioffi (University of California at Riverside), Lindsay Krauss (Osgoode Hall Law School, Toronto, Production Editor) 

CLPE Research Paper 20/2007

Vol. 03 No. 05 (2007)

\section{Special Symposium Issue: EU Governance}

PROCEEDINGS FROM THE $10^{\text {TH }}$ IRISH EU LAW FORUM, UNIVERSITY COLLEGE

DUBLIN, 19 JANUARY 2007

\section{Simon Deakin}

\section{REFLEXIVE GOVERNANCE AND EUROPEAN COMPANY LAW}

Abstract: The use of reflexive forms of regulation is growing within the EU, in particular as the open method of coordination ('OMC') is applied to a growing number of contexts including employment policy, social inclusion, enterprise promotion, environmental protection, energy policy, and fundamental human rights. Company law, however, seems to be an exception to this: recent activity has taken the form of 'hard law' harmonization through directives, coupled with the stimulation of regulatory competition through judgments of the European Court of Justice in relation to freedom movement, stemming from the Centros case. There is a very limited 'company law OMC' in the form of the deliberations of the European Corporate Governance Forum, but there is little evidence here of what proponents of the OMC call 'learning from diversity'; instead, the Forum appears to envisage the elimination of country-specific practices which it refers to as 'distortions of competition'. This paper argues that the lack of a meaningful company law OMC is likely to prove a more serious long-term obstacle to capital market integration than the persistence of inter-country variations in corporate governance practices. The example of labour law shows how functional convergence and a coordinated raising of standards can be achieved by the dovetailing of the OMC with social policy directives. By contrast, the recent failure of the Takeover Directive to impose a uniform model of takeover regulation indicates the limits of top-down modes of harmonization. At the same time, the case of labour law highlights the importance of placing the OMC within a wider framework of legal support 
for fundamental rights, of the kind which is capable of providing a countervailing force against court-led deregulation.

Keywords: corporate governance, open method of coordination, European company law

JEL classification: G34, K22, K33

Author Contact: Simon Deakin Assistant Director, Centre for Business Research

Faculty of Law and Centre for Business Research, Cambridge University Top Floor, The Judge Business School Building Trumpington Street, Cambridge, United Kingdom, CB2 1A2

Email: s.deakin@cbr.cam.ac.uk 



\title{
REFLEXIVE GOVERNANCE AND EUROPEAN COMPANY LAW
}

\author{
Simon Deakin
}

\section{INTRODUCTION}

There has recently been considerable interest in the emergence of distinctive forms of governance in the EU, of which the open method of coordination is the best known, which involve the use of reflexive or responsive techniques of regulation. 'Reflexive governance', in this sense, implies that diversity of practice among the member states is a resource which, when coupled with open coordination methods such as benchmarking and mutual monitoring, provides a basis for experimentation and mutual learning. This approach has been contrasted to more traditional forms of harmonization of laws through directives, on the one hand, and to court-led regulatory competition, with its implication of deregulation, on the other. The open method is currently exercising considerable influence in such diverse areas as employment policy, social inclusion, enterprise promotion, environmental protection, energy policy, and fundamental human rights.

Corporate governance is, however, an apparent exception to this trend. In this area, the Commission, in its proposal for the measure which eventually became the Thirteenth Company Law Directive, on takeover bids, and its proposals for a rolling programme of corporate governance reforms, effectively endorsed the principal-agent model of corporate governance which is most closely associated with American, and to a lesser degree, with British practice. The diversity in corporate governance structures and practices which currently exists across member states is, in

\footnotetext{
* Faculty of Law and Centre for Business Research, University of Cambridge (http://www.cbr.cam.ac.uk/people/deakin.htm). This paper was prepared for the Irish European Law Forum, Tenth Annual Conference, Regulating Liberalising Markets and Social Europe: New Governance in the EU, University College, Dublin, 19 January 2007. I am grateful for comments received from participants in the Forum.
} 
this view, not an occasion for learning, but a potential distortion of competition.

This paper considers the implications of the recent experience of company law reform for emerging forms of governance in the EU, and uses the company law case to frame a wider discussion of the prospects for the European social model during a period of market liberalisation. Could it be that the method of open coordination will be applied in future to areas, such as employment and social policy, in which a political consensus at EU level of the kind needed to underpin new legislative measures, such as directives, is unlikely to emerge; but that hard-law mechanisms, including not just harmonization but also court judgments inducing regulatory competition, will be used to reshape other aspects of the internal market, including corporate governance? What are the risks involved in taking an asymmetrical approach - a process of mutual observation and 'learning by monitoring' for social and employment policy, but hard-law intervention based on a single 'best' model in the case of company law and the internal

market? To analyse these questions, section 2 outlines the emergence of reflexive forms of governance within the EU and explores some of the theoretical ideas underpinning them. Section 3 then look in more detail at some recent substantive developments in the fields of company law and social policy, and discusses how far they map on to the models of governance which are to be found in the theoretical literature. Section 4 offers an assessment and conclusion.

\section{MODELS OF GOVERNANCE IN THE EU}

The case for viewing the EU as an innovator in respect of forms of governance has been powerfully made by Charles Sabel in a series of papers (see Cohen and Sabel, 1997; Gerstenberg and Sabel, 2002), most recently with Jonathan Zeitlin (2006). According to this view, 'distinctive and surprisingly effective innovations' have emerged, the essence of which is that 'the EU is creating a single market while constructing a framework within which the member states can protect public health and safety in ways that grow out of these traditions and allow them to pursue their own best judgements for innovative advance' (Sabel and Zeitlin, 
2006: 1-2). This analysis goes further than merely acknowledging, as others have done, the role of deliberation through the role of 'comitological' committees, or even the use of forms of multi-level 'concertation' which tend to dissolve the distinctions between a central 'core' of decision-making and national 'peripheries'. In addition, a new 'underlying architecture of public rule making' can be observed; this 'can neither be mapped from the topmost directives and Treaty provisions nor read out from any textbook account of the formal competences of EU institutions', but it nevertheless 'regularly and decisively shapes EU governance'. Its essence is the establishment, firstly, of 'framework goals', jointly set by action between the member states and EU institutions, such as the goal of a high employment rate set for the employment policy OMC in the late 1990s; secondly, the devolution to 'lower level units', a category including but not limited to member states, of the means of implementation of these goals; thirdly, the application of a duty on the part of those units to report on their performance, to benchmark it against agreed criteria, and to take part in a peer review process by which their performance is judged collectively; and, fourthly, a recursive mechanism through which the framework itself is periodically revised in the light of the information produced by the benchmarking process.

The result is distinctive, it is argued, for the following reasons (Sabel and Zeitlin, 2006: 4-10). Firstly, the goal of deliberation is not, as has been thought, to reach agreement in the sense of a 'reflective equilibrium'; rather, 'deliberative decision making is driven at least as much by the discussion and elaboration of difference'. Secondly, the result is not, necessarily, to replace formal norms with informal ones: 'those institutions whose explicit purpose is to expose and clarify difference so as to destabilize and disentrench settled approaches are typically highly formalised'. It is not simply that formal revisions to directives and national-level laws often result from the processes concerned; even where formal laws and sanctions are absent, the consequences of non-compliance can be far-reaching, in terms of possible economic losses and harm to reputation. Thirdly, new forms of governance rest not so much upon the imposition from above of supposedly optimal regulatory solutions, as upon a clear division of labour between EU institutions with responsibility for devising frameworks of general application, and the member states whose task is to adapt them to local conditions and to contribute, through 
reporting and monitoring, to a collective learning process: 'the most successful of these arrangements combine the advantages of decentralized local experimentation with those of centralized coordination, and so blur the distinction between forms of governance often held to have incompatible virtues'. What this adds up to is a type of governance termed directly deliberative polyarchy - 'polyarchy' here refering to the element of mutual learning through monitoring by lower level units which is, in essence, 'a machine for learning from diversity' (Sabel and Zeitlin, 2006: 7-8).

The core illustration of the operation of deliberative polyarchy as a distinctive form of governance in the EU, although by no means the only one, is the 'open method of coordination' formally adopted at the Lisbon summit in 2000. Formally, this had four elements: the fixing of guidelines at central level, coupled with timetables for the achievement of goals; the establishment of benchmarks for tailoring performance and allowing the identification of best practice at local level; the adoption of specific targets for the implementation of guidelines, while taking into account regional and national differences; and a process of 'periodic monitoring, evaluation and peer review organized as mutual learning processes'. Elements of the OMC were already in existence, in the form of the Broad Economic Policy Guidelines which can be traced back to the Treaty of Maastricht, and the Employment Guidelines adopted in relation to the European Employment Strategy which was formally embedded in the Treaty of Amsterdam. The Lisbon Summit stimulated a proliferation of new OMCs across a wide range of areas, which now include pensions policy, strategies on social inclusion, and policies on fundamental rights, while looser variants of the same idea have been applied in the contexts of research and innovation policy, the 'information society', and the promotion of small and mediumsized enterprises.

The arrival of the OMC appears to mark a fundamental break with what came before, and this is often the way in which it has been portrayed by critics and opponents alike. The authors of the OMC, as Sabel and Zeitlin put it, saw it as 'a "third way" for EU governance between regulatory harmonization and fragmentation' (2006: 27). However, there is a case for identifying important continuities between the OMC and some longstanding debates about the proper role of harmonization within the common, later the single, market. 
The EU neither had, nor has now, a general power to regulate labour and capital markets in the interests of promoting inter-state trade, in contrast to the position, for example, under the federal United States constitution, whose commerce clause is much more extensive in this regard than its EU counterparts. The EU's social policy powers were extremely limited from the start (see Deakin, 1996). The Treaty of Rome contained only a few provisions on labour law; the most important was Article 119 (now 141), which enshrined the right to equal pay between men and women. This provision owed its existence to French concerns that its apparently more protective sex discrimination laws would be a source of competitive disadvantage. A similar justification led to the inclusion of a Treaty provision relating to annual leave rights. But for the most part, social policy was outside the scope of the Treaty. This was no accident. The founders of the European Economic Community accepted the view, set out in a report commissioned from the ILO, that harmonizing measures in the labour law field were unnecessary. The implementation of the common market was expected to lead to upward pressure on wages and social welfare provisions, as states competed to attract scarce labour. At the point, in the mid-1950s, when the member states were all politically committed to the expansion of the welfare state and to the maintenance of conditions of full employment, this was not an unreasonable assumption. It was not until the early 1970s, when the EEC's expansion from six to nine states coincided with the end of the post-war consensus on the welfare state and full employment, that the member states felt it necessary to instigate the Community's first social action programme. This led to directives on equality of treatment and employment protection, which were adopted using general powers to regulate the common market. These initiatives paved the way for the significant expansion of social policy measures in the 1980s during the period of the Delors presidency. The Single European Act of 1986, the Treaty of Maastricht in 1992 and the Treaty of Amsterdam in 1997 each led to a widening of legislative powers in the social policy field, but it remains the case that these powers are narrowly confined, with certain areas (most notably minimum wages, collective bargaining and the right to strike) excluded altogether from the law making powers of the Community's central organs. In effect, state autonomy is still the order of the day in the social policy field, with only marginal incursions from Community law. 
The power to introduce harmonising measures in the field of company law was, by contrast to those applying to social policy, both more extensive, and more closely related to the original economic objectives of the Community, since it originated in the freedom of establishment provisions of the Treaty of Rome. Under Article 54(3)(g) of the Treaty of Rome (now 44(2)(g) of the EC Treaty), the Council was empowered to adopt directives aimed at 'coordinating to the necessary extent the safeguards which, for the protection of the interests of members and others, are required by Member States of companies and firms... with a view to making such safeguards equivalent throughout the Community'. Thus an element of uniformity in the laws protecting the right of shareholders and 'others' (this phrase could cover a range of stakeholder interests) was thought to be necessary in order to forestall a 'race to the bottom'. Directives were adopted from the late 1960s onwards, and by the early 1970s some commentators were arguing that the Community needed a thorough-going harmonization programme; the 'virtual unification of national company laws' (Schmitthoff, 1973: 9) would ensure that a race to the bottom was avoided.

However, the prescriptive approach of the first company law directive gave way to so-called 'second generation' measures which set out basic accounting and audit standards in the form of a menu of options based largely on existing member state practice (Villiers, 1998). Member-state autonomy was also observed in the 'third generation' measures which were based on the principle that harmonization should be limited to interventions which could be shown to be essential to the functioning of the single market, and in the 'fourth generation' or framework directives of the 1990s which were based on the articulation of general principles rather than detailed prescription and which involved a degree of delegation of rule-making powers to trade and professional bodies at both member state and transnational level.

There is therefore a case for saying that reflexive forms of governance, involving a division of labour between EU institutions and the member states and commitment to experimentalism based on diversity of practices, were part of the EU's regulatory architecture from the outset. The decision to attempt even the limited degree of harmonization in labour and capital markets which was initially envisaged through directives, as opposed to regulations which are directly applicable in national law, was 
itself significant. Directives are not self-enforcing; they depend for the effectiveness on implementing measures taken by member states. Directives in the social policy field are by and large designed to set a 'floor of rights'. This model was established in the 1970s and, with some modifications and adaptations, remains the principal approach today. Most directives make explicit reference in their texts to 'minimum standards' which states must observe but on which they can improve, while many also contain 'non-regression clauses' which are intended to prevent member states from using the implementation of a directive to reduce the pre-existing level of protection guaranteed by national law. A 'race to the top' is thereby encouraged.

This distinctive European approach to the regulation of transnational markets has been described using the term reflexive harmonization (Deakin, 1999, 2001, 2006; Barnard and Deakin, 2002; Zumbansen, 2006). Rather than seeing reflexive forms of governance as a 'third way' between the standardisation and fragmentation of laws, as supporters of the OMC would have it, the guiding idea here is that there is no necessary opposition between regulatory competition and harmonization. Regulatory competition, rather than inevitably involving a race to the bottom, should be seen as a process of discovery through which knowledge and resources are mobilized in the search for effective and workable rules. The concept of 'reflexive harmonisation' is an adaptation of the idea that competition is a learning process dependent on norms that establish a balance between 'particular' and 'general' mechanisms (Sugden 1997: 48); between, that is, the autonomy of local actors, and the mechanisms which ensure a process of collective learning based on observation and experimentation. As with theories of deliberative polyarchy, an essential prerequisite for reflexive harmonization is the preservation of local-level diversity, since without diversity, the stock of knowledge and experience on which the learning process depends is limited in scope. However, there are several respects in which the reflexive harmonization approach differs from deliberative polyarchy.

The theory of reflexive harmonization was developed as part of an explicit engagement with, and response to, neoliberal critics of the EU's role in transnational rule-making. Those, for example, who argued against the European Commission's social action programmes of the 1980s and 1990s, did so on the grounds that variety within the Union as a whole 
should be preserved: 'hidden in the historical experience of economic integration, there is ... a very important aspect of "system dynamics": international competition in the field of the welfare state serves as a kind of process of discovery to identify which welfare state package - for whatever reason - turns out to be economically viable in practice' (Paqué, 1997: 109). As this critique recognized, there was a strong argument against the use of harmonizing legislation to cement in a single 'best' solution. However, the theory of reflexive harmonization argued that this was not a good account of how EU governance worked. It argued, as we have just seen, that European-style harmonization had evolved to play the role of maintaining the appropriate relationship between 'particular' mechanisms operating at the sub-federal level, and the 'general' mechanisms by which learning across the Union as a whole took place. The model of reflexive harmonization held that the principal objectives of judicial intervention and legislative harmonization alike were two-fold: firstly, to protect the autonomy and diversity of national or local rulemaking systems, while, secondly, seeking to 'steer' or channel the process of adaptation of rules at state level away from 'spontaneous' solutions which might lock in sub-optimal outcomes, such as a 'race to the bottom' initiated by court-led 'negative harmonisation'. In contrast, the deliberative polyarchy approach is silent on the role that minimum standards might play in shaping the process of transnational integration. There is nothing in the deliberative polyarchy approach to suggest, for example, that experimentalist solutions of a deregulatory type should be ruled out in principle, and nor is there any clear engagement with the risks which this type of regulatory competition might pose.

The idea of reflexive harmonization was also advanced by way of an explicit contrast with US experience. It was common, in critiques of the EU's harmonization programmes in the 1980s and 1990s, to contrast a US model of state autonomy and inter-jurisdictional competition with a European one centred on the application of uniform rules. However, reflexive harmonization theory argued that this view as mistaken. This was because federal legislation in labour and capital markets had been a highly significant presence in the US context since the passage of the New Deal legislation of the 1930s. The law governing collective bargaining and union security was federal law, in the form of the National Labour Relations Act, which is composed of the Wagner Act of 1935 and the amending Taft-Hartley Act 1949. Thanks to the doctrine of pre-emption, 
these federal statutes occupied the field to the exclusion of state law. It was only in those areas where the federal legislature had carved open a space for state-level initiative that regulatory competition had been able to develop. A good example of this was the leeway granted to states by the Taft-Hartley Act, to enact exceptions to union security laws which underpinned the closed shop. This had led to the introduction of 'right to work' statutes in many southern and western states in the 1950s and 1960s. Laws which might have improved on the protective standards set out by the federal legislation were ruled out by the pre-emption doctrine. In effect, a race to the bottom in labour standards was still possible, but a race to the top had been ruled out, the inverse of the situation in the EU. The result was the opposite of an experimentalist solution: the rigid and, in the view of many commentators, flawed structure of workplace representation set out in the legislation of the 1930s remained fixed in place (Weiler, 1990).

In company law, too, the US experience pointed to the dangers of allowing regulatory competition to operate unconstrained. The popular image was one of a self-forming corporate law emerging on the basis of regulatory competition between the states (the 'Delaware model'). However, this masked the wider picture. In the area of securities law, the Securities Act 1933, the Securities and Exchange Act 1934 and, more recently, the Sarbanes-Oxley Act 2002, were all federal statutes. Delaware had, at best, a precarious independence from federal control; formally, company law remained the responsibility of the states, but federal securities law was always in danger of spilling over into the domain supposedly set aside for company law to be set by state courts and legislatures. Thus the federal legislator had come to act both as a competitor to Delaware, and, to a certain degree, as an implicit regulator of inter-jurisdictional competition (Roe, 2005). At the same time, Delaware's pre-eminence had led to a situation in which the degree of diversity across the different state jurisdictions was far below that which could be found in the EU (Deakin, 1999, 2001). This was the consequence of the freedom which companies had to incorporate in the state of their choice, and of a strong version of the mutual recognition principle, under which courts in all states were required to recognize that choice as far as the 'internal affairs' of the corporation were concerned. In the EU, at least until the Centros case was decided (on which, see below), states were free to retain the 'real seat' principle under which a company's applicable law was the state in which 
its head office was situated or with which it had the strongest functional connection. This was a vital protection against the 'race to converge' which the US had experienced as states clustered around the essential features of the Delaware model.

The theory of deliberative polyarchy, by contrast, sees the EU as simply one case amid a larger set of emerging governance forms to be found at national, regional and global level. Thus Sabel and Zeitlin cite instances of experimentalism in the US including environmental protection, education policy, child protection, and food safety. To some degree, their emphasis on EU-US similarities may simply reflect a particular selection of substantive areas of law on which to focus; they do not discuss labour or company law, both areas of considerable divergence (as we have just seen), in any detail. Nevertheless, they are prepared to extend the deliberative model to cover global-level governance too: 'developments cast doubt on the singularity of the EU's innovative regulatory architecture' (Sabel and Zeitlin, 2006: 71), with the WTO and ILO, among others, beginning to borrow elements of the OMC approach.

Whether the OMC truly represents a template for the global governance of the near future is a matter to which we shall return. The next step in the analysis is to consider how far the models of governance just described are reflected in some recent substantive developments in the areas of company law and labour law.

\section{RECENT DEVELOPMENTS IN GOVERNANCE AT EU LEVEL: COMPANY LAW AND LABOUR LAW COMPARED}

Since the turn of the century there has been what seems, on the face of it, to be a huge increase in the volume and range of EU level company law. Important new directives have been adopted on takeover bids, ${ }^{1}$ cross-

${ }^{1}$ Directive 2004/25/EC on takeover bids. 
border mergers, ${ }^{2}$ the responsibilities of boards for financial statements and key non-financial information, ${ }^{3}$ transparency requirements for publicly traded companies, ${ }^{4}$ the conditions for incorporating a company as a Societas Europaea or European Company, ${ }^{5}$ and the rights of shareholders in listed companies. ${ }^{6} \quad$ Two significant recommendations have been published, one on directors' remuneration ${ }^{7}$ and one on the duties of nonexecutive or supervisory directors and the role of committees of the board. ${ }^{8}$ Corporate governance now has its own OMC, of a kind, thanks to the establishment of a process deliberation over principles of general application, under the auspices of the European Corporate Governance Forum.

By contrast, labour law initiatives seem log-jammed. Three measures, on parental leave, part-time work and fixed-term employment, ${ }^{9}$ were adopted in the late 1990s as 'framework agreements' under the social dialogue procedure which enables the force of a directive to be given to accords made by the social partners at EU level, and a new directive on

2 Directive 2005/56/EC on cross-border mergers of limited liability companies.

3 Directive 2006/46/EC on board responsibilities and improvement of financial information relating to financial and corporate governance matters.

${ }^{4}$ Directive 2004/109/EC on the harmonisation of transparency requirements in relation to information about issuers who securities are admitted to trading on a regulated market.

${ }^{5}$ Regulation 2001/2157/EC on the Statute for a European company (SE) and Directive 2001/86/EC supplementing the Statute for a European company with regard to the involvement of employees.

6 This measure was formally adopted in June 2007. For the provisional text, see Directive of the European Parliament and of the Coucil on the exercise of certain rights of shareholders in listed companies, PE CONS 3608/07, 1 June 2007.

7 Recommendation 2004/913/EC fostering an appropriate regime for the remuneration of directors of listed companies.

8 Recommendation 2005/162/EC on the role of non-executive or supervisory directors of listed companies and on the committees of the (supervisory) board.

9 Directive 96/34/EC on the framework agreement on parental leave UNICE, CEEP and the ETUC, Directive 97/81/EC concerning the framework agreement on part-time work concluded by UNICE, CEEP and the ETUC, and Directive 99/70/EC concerning the framework agreement on fixed-term work UNICE, CEEP and the ETUC. 
information and consultation of employees was agreed in 2002, ${ }^{10}$ after the failure of the social dialogue process in this case. Since then, there has been a failure to reach agreement on the revision of the Working Time Directive, and it is widely believed that new measures in the social policy field, at least in so far as they are concerned with substantive regulation of terms and conditions of employment as opposed to procedures for information and consultation of employees, will struggle to win political acceptance. While labour law is stalled, attention has focused instead on the employment strategy OMC, which, has generated an active debate about the merits and demerits, from the point of view of competitiveness, of particular features of national labour law systems.

This preliminary view, of a strong contrast between the different trajectories of company and labour law at EU level since 2000 or so, is not entirely false, but closer inspection suggests that the recent experiences share certain common features.

There are elements of the legislative programme in company law which conform to a conception of harmonisation as standardization, and which as a result have little if any common ground with deliberative or reflexive approaches. The first significant document in the current round of initiatives was the report of the High Level Group of Experts on takeover bids, published in October 2002. This argued that what the EU needed was 'an integrated capital market' in which 'the regulation of takeover bids [would be] a key element' (High Level Group, 2002a: 18). The report noted that 'the extent to which in a given securities market takeover bids can take place and succeed is determined by a number of factors', including general or structural factors affecting financial markets, and company-specific factors such as rules of company law and articles of association affecting voting rights, protection of minority shareholders, and the legitimacy of takeover defences. It then observed that 'there are many differences between the Member States in terms of such general and company specific factors', with the result that the EU lacked a 'level playing field'.

${ }^{10}$ Directive 2002/14/EC establishing a general framework for informing and consulting employees in the European Community. 
The substantive content of state-level company laws was also an issue for the High Level Group. The essence of the problem was that the laws of most member states did not sufficiently conform to a model of corporate governance in which managers understood their principal duty to return value to shareholders, and in which takeovers played a crucial disciplinary role in reminding them of this obligation:

'actual and potential takeover bids are an important means to discipline the management of listed companies with dispersed ownership, who after all are the agents of shareholders. If management is performing poorly or unable to take advantage of wider opportunities the share price will generally under-perform in relation to the company's potential and a rival company and its management will be able to propose an offer based on their assertion of their greater competence. Such discipline of management and reallocation of resources is in the long term in the best interests of all stakeholders, and society at large. These views also form the basis for the Directive' (High Level Group, 2002a: 19).

The High Level Group could not have been clearer: they were proposing a measure based on the standard finance-theory or 'principal-agent' view of the role of hostile takeover bids in enhancing shareholder value. The assertion that managers are 'after all' the agents of shareholders in one based on a particular economic-theoretical position, and has no grounding in the legal conceptions of the company which the High Level Group might have looked for in the laws of the Member States. Even UK company law does not go this far; it has not followed the Delaware practice of sometimes referring to duties owed by directors to the shareholders rather than to the company as a separate entity. Be that as it may, it was very largely to the UK that the EU experts looked to fill out the content of the Directive. Even more so than its many predecessors, this draft of the Thirteenth Directive drew on the model of the City Code on Takeovers and Mergers, a text notable for the high level of protection it gives minority shareholders and for its restriction of poison pills and other anti-takeover defences which US law, which is other takeover-friendly, by and large allows (see Deakin and Slinger, 1997). 
The High Level Group's second report, in November 2002, struck a similar note in stressing the role of non-executive directors in monitoring management, which is a feature of British and American practice, but is relatively underdeveloped in other member states:

'Good corporate governance requires a strong and balanced board as a monitoring body for the executive management of the company. Executive managers manage the company ultimately on behalf of the shareholders. In companies with dispersed ownership, shareholders are usually unable to closely monitor management, its strategies and its performance for lack of information and resources. The role of non-executive directors in one-tier board structures and supervisory directors in two-tier board structures is to fill this gap between the uninformed shareholders as principals and the fully informed executive managers as agents by monitoring the agents more closely' (High Level Group, 2002b: 59).

Again, the standard finance-orientated or 'principal-agent' model was stressed, and a feature of the British and American systems was presented as if it had universal validity. Features of national systems which did not conform to the principal-agent approach, such as the distinctive role of worker directors and community representatives in two-tier boards, were simply shoehorned into the supposedly universal model. The High Level Group's second report set out a series of objectives for reform of corporate governance (among other things) which reflected this point of view, and which were then incorporated into the Commission's Action Plan on company law, with effect from 2003. ${ }^{11}$

What happened next, and in particular the fate of the Thirteenth Directive, is instructive. Although the Directive was eventually adopted, in 2004, ${ }^{12}$ this was only after a series of compromises had been agreed, which

11 See High Level Group, 2002a: 10-12. On the Action Plan, and its development since 2002, see Commission, 2003, and the company law website of the Internal Market Directorate: http://ec.europa.eu/internal_market/company/index_en.htm.

12 Directive 2004/25/EC. 
considerably diluted the draft presented by the Commission in 2002 . Contrary to the expectation that the Directive would roll out a liberalmarket model of takeover regulation along similar lines to that of the UK's City Code on Mergers and Takeovers, in its final form it allows member states to retain laws which permit multiple voting rights and limit shareholder sovereignty in various ways, such as allowing anti-takeover defences to be put in place in advance of bids. Some of these provisions are transitional; the general thrust of the Directive is still in favour of the principle of one share one vote and proportionality between investment risks and decision-making powers, is clear. Yet, rather than impose a single model on member states, the Directive can be seen as setting out an experimentalist framework for law-making at state level. This was far from being its original objective. But the result of the rough-hewn compromises which informed the final text of the Directive is that the liberalisation of takeover rules can be achieved in one of several different ways, which may take into account specific features of the legal and institutional environments of the different member states.

Another significant feature of the Thirteenth Directive is that provision was made for the reformed takeover rules to make provision for information and consultation of employees. An element of employee consultation was present in earlier drafts of this Directive, and the provisions on this issue which were included in the final text are not especially far-reaching, and do not go as far as the laws of a number of member states. However, the Thirteenth Directives set a pattern, in that mandatory employee consultation provisions were then included in other company law directives, including the directive on cross-border mergers, as well as the Societas Europaea measures (where again there has been a long debate on this issue). This illustrates the complexities involved in translating the principal-agent model of corporate governance into specific legal provisions. The finance theory espoused by the High Level Group finds no room for managerial engagement with employees on issues of corporate governance, regarding it as a qualification to the principle of shareholder-based control of the firm. However, the issue of employee involvement is unavoidable when it comes to legislating at EU level. This is not just because organised labour interests have numerous possibilities for presenting their view when directives are being formulated, but also because the principle of employee consultation in the event of corporate restructurings has come to be recognised, over several decades, as an 
important point of reference within the EU legal order, as it is embodied in numerous labour law directives as well as in the EU Charter of Fundamental Rights. It was never going to be likely that the new company law directives could simply ignore the issue.

A further paradoxical and perhaps unexpected consequence is that, following the adoption of the Thirteenth Directive, the UK rules on takeover bids have had to be substantially modified in order to accommodate the employee consultation principle. The UK's City Code may have provided the model for the Directive, but the Code could not remain unaffected by the wider implications for corporate governance of the Directive's adoption. In particular, more prescriptive provisions concerning the potential impact of takeovers on employees have had to be introduced. The bidder must now provide detailed information on its strategic intentions with regard to the target, possible job losses, and changes to terms and conditions of employment, ${ }^{13}$ and the target must give its views, in the defence document, on the implications of the bid for employment. ${ }^{14}$ Breach of these provisions is a criminal offence, and they have potentially significant implications for employees' consultation rights under UK labour law (see Deakin, 2007). In addition, employee representatives of the target have the right to have their views of the effects of the bid on employment included in relevant defence document issued by the target. ${ }^{15}$ The full impact of these rules on UK takeover law and practice remains to be seen, but their adoption illustrates the destabilizing effects which the process of EU law making can often have on apparently entrenched arrangements at state-level.

There are other signs that the so-called modernisation of company law is not proceeding in a straightforwardly linear fashion towards the instantiation of the agency model, and that the reform process has had to take on board the diversity of state-level practices. Corporate governance even has its own OMC-type mechanism, thanks to the establishment of

13 City Code, rule 24.1.

14 Ibid, rule 25.1(b).

15 City Code, rule 30.2(b). This is however subject to the target board receiving the employee representatives' views in good time, which may not always be straightforward. See Takeover Panel 2006: 32-3, for discussion. 
establishment in 2003 of the European Corporate Governance Forum. The Forum's existence was prefigured in the November 2002 report of the High Level Group, which recommended that the Commission

'set up a structure which facilitates the coordination of the Member States' efforts to improve corporate governance. Member States should be required to participate in the coordination, but the process itself and the results of the process should be voluntary and non-binding. Market participants (including of course companies) should be invited to be actively involved in the coordination exercise' (High Level Group, 2002b: 73).

In practice, the European Corporate Governance Forum represents something less than a fully fledged OMC for company law. Its members, '15 outstanding high level experts in corporate governance', ${ }^{16}$ are selected by the Commission. The composition of the group is intended 'to ensure a balanced representation of all those having an interest in sound corporate governance practices: investors, issuers, regulators, worker representatives and academics'. 17 The task of the Forum has been described as 'to help the convergence of national efforts, encourage best practice and advise the Commission'. ${ }^{18}$ It meets three times a year and its published minutes indicate that most of its business so far has been devoted to discussion of a number of corporate governance issues, most notably the operation of the 'comply or explain' principle in state-level codes (that is, the principle that companies may either comply with the provisions of codes on board structure and other aspects of governance, or issue a statement explaining why they have not done so). As part of this process, the Forum a statement of its own on the 'comply or explain' principle which is akin to a guidance note. The Forum has expressed its intention to approach regulatory bodies and other relevant organs at member state level with a view to collecting information on corporate governance practices, but

16 Speech of Commissioner Bolkestein, European Corporate Governance Conference, The Hague, 18 October 2004, available on the Internal Market Directorate company law website: http://ec.europa.eu/internal_market/company/index_en.htm.

17 Ibid.

18 Ibid. 
whether this will mature into a peer-review or benchmarking process, is not yet clear.

Only one trade unionist sits on the group; most of its members are senior representatives of financial industry trade associations, institutional shareholder groups, and bodies which campaign for enhanced shareholder protection. At its June 2006 meeting, the Forum heard a presentation from the European Trade Union Confederation on the role of employees as stakeholders in corporate governance. The nature of the Forum's likely future attitude to issues of employee involvement can be inferred from this entry in the minutes:

'members pointed out to possible risks of including employees and other stakeholders into the corporate governance debate. In some cases, their interests are used by the management as an excuse for following its own line and acting contrary to the interests of the shareholders. This can even result into being detrimental to the employees who increasingly are shareholders themselves, either directly or through their pension funds. One member also pointed out to the OECD principles [on corporate governance] that deal with the position of employees only in very general terms and took the view that the Forum should stay within that framework'. ${ }^{19}$

In other respects, there are signs that both the Forum and the Internal Market Directorate to which it reports are broadly committed to the convergence of EU systems around the global corporate governance standard embodied in the OECD principles, and which is closely aligned to US and UK practice. While references are made to the importance of understanding diversity in the company laws of the member states, there is an underlying emphasis on the role of the Commission in encouraging convergence. Sometimes this takes the form of the suggestion that ' $a$ process of convergence in Member States's approaches to Corporate

19 Minutes of the Sixth Meeting of the European Corporate Governance Forum, 1 June 2006, available on the European Corporate Governance Forum website: http://ec.europa.eu/internal_market/company/ecgforum/index_en.htm. 
Governance is already underway', ${ }^{20}$ with comply or explain being used as the foremost illustration; on other occasions, the need for further reforms is stressed:

'Why should the Commission step up to meet the challenge and become embroiled in matters which most often depend on national laws and regulations, as well as traditions and practices? Basically because what is at stake is of enormous concern at the European level, cannot be achieved solely through competition across systems, and sometimes requires a determined fight against perverse national behaviour. Corporate governance differences and related discrepancies in corporate law are very often powerful barriers to integration, which stand in the way of the Internal Market. If these barriers did not exist, if investors could not confidently buy equity in countries other than their own and feel that they had the same rights and obligations as in their home markets, if the control of a corporation was open to the most competent managers, irrespective of their nationalities, the efficiency of European capital markets would improve markedly, and the quality and performance of management would certainly have to meet higher standards'. ${ }^{21}$

As we have seen, the Forum has not yet got to the state of initiating a benchmarking programme designed to test member states' compliance with what it takes to be internationally accepted corporate governance standards; similarly, the Internal Market Directorate has stated that it has no intention of initiating a harmonisation programme aimed at removing national 'discrepancies', and has set its face against such initiatives such

20 Speech of Commissioner Bolkestein, Conference on the German Corporate Governance Code, 24 June 2004, available on the Internal Market Directorate company law website: http://ec.europa.eu/internal_market/company/index_en.htm.

21 Speech of Mr. Antonio M. Borges, member of the European Corporate Governance Forum, to the Hearing on Future Priorities for the Action Plan on Company Law and Corporate Governance, Brussels, 3 May 2006, available on the Internal Market Directorate company law website: http://ec.europa.eu/internal_market/company/index_en.htm. 
as the promulgation of an EU-wide corporate governance code. But this does not mean that it is neutral on the question of the kind of company law systems and corporate governance regimes to which EU member states should be moving. There is a growing stress, not on harmonisation in the traditional sense of the standardisation of rules, nor even on open coordination as a basis for mutual learning, but instead on a framework of rules which will bring about convergence by providing maximum crossborder mobility for capital. The emerging principle is that ' $[\mathrm{w}] \mathrm{here}$ various alternative systems exist in Member States for elements of the company's organisation and structure, the EU should as much as possible facilitate freedom of choice between these alternative systems for companies across Europe, rather than trying to agree upon one specific EU system or leaving the option to Member States '.

This view fits in with the wider market liberalisation agenda of the Internal Market Directorate, as expressed in the case of the Services Directive among others, and with the ECJ's decision in the Centros case, ${ }^{22}$ which by casting considerable doubt on the 'real seat' principle, has opened up the possibility of regulatory competition along US lines finally arriving in the EU.

The ECJ's case law has long accepted the principles of mutual recognition and non-discrimination, albeit with some significant doctrinal distinctions according to the precise context which is being considered. However, these principles have also been subject both to provisions of the EC Treaty itself which embody a number of derogations on public policy grounds from the free movement principle, and to a further set of derogations developed by the Court itself as its jurisprudence has evolved. Thus from the inception of this process, respect for the autonomy and territorial sovereignty of the member states has operated as a countervailing force to pressure for economic liberalisation.

The Centros case placed critical pressure on this long-standing compromise. Only a minority of member states observe the state of incorporation rule under which a company is free, by virtue of its decision on incorporation, to choose the law which applies to its internal

${ }^{22}$ Case C-212/97 Centros Ltd. v. Erhvervs-og Selkabsstryrelsen, [1999] ECR I-1459. 
governance. Most member states have traditionally observed the real sea principle which generally means that courts will regard the applicable law as that of the member state in which the company has its main centre of operations - its head office or principal place of business. The effect has been to render impossible the kind of market for corporate charters or constitutions which operates in the US, since a company cannot switch its state of incorporation at will. The legality of the siège réel doctrine was an obvious target for free movement jurisprudence from an early stage but the process took a decisive turn in favour of a strict reading of the free movement principles after Centros. Two Danish citizens incorporated a private company of which they were the sole shareholders, named Centros Ltd., in the UK. One of the two shareholders then applied to have a 'branch' of the company registered in Denmark for the purposes of carrying on business there. Centros Ltd. had never traded in the UK. The Danish Registrar of Companies refused to register the branch, on the grounds that what the company was trying to do was not to register not a branch or overseas presence, but its principal business establishment. The Registrar took the view that Centros Ltd. had been incorporated in the UK in order to avoid Danish minimum capital requirements which are designed to protect creditors and minimise the risk of fraud. The Court ruled that the refusal to accede to the registration request was contrary to the freedom of establishment principle. The ruling by no means closes the door to a proportionality-type argument to the effect that the measure in question meets a legitimate aim of public policy in an acceptable way. However, the rather peremptory way in which the Court brushed aside the policy arguments in favour of creditor protection legislation in Centros (see Deakin, 1999) does not bode well for any future attempt to argue that the maintenance of the real state principle for the purpose of upholding codetermination laws, for example, can be justified on the grounds of the economic and social benefits of employee participation in the processes of corporate governance.

Employee representation rights in the context of cross-border movements of capital is one of the issues being addressed by the Commission as part of the process of consultation over the draft Fourteenth Company Law Directive. But the Fourteenth Directive, assuming it is ever agreed, may be too little, too late. The response of the corporate sector to Centros and related case-law indicates some potential consequences of going down the path of uncontrolled regulatory competition. Tens of thousands of Danish 
and German SMEs have incorporated or reincorporated in the UK, taking advantage of Centros to avoid minimum capital requirements (see Armour, 2005; Becht, Mayer and Wagner, 2005), and several countries have begun to water down their creditor protection laws. Corporate migration is also being motivated by the desire to avoid codetermination laws. In May 2006 the German airline Air Berlin registered as a UKbased plc, apparently in order to avoid German codetermination laws, a move which, it has been predicted, others will follow. ${ }^{23}$

As already noted, labour law reform has proceeded at a much slower pace, in the 2000s, than has been the case for company law, and attention has focused instead on the OMC for employment strategy, which is much more highly developed, and institutionally embedded, than its company law counterpart. This does not mean, however, that labour law has stood still. The employment strategy OMC has stimulated a debate about the appropriate balance between flexibility and inclusion in labour law which is reflected in the Commission's 2006 Green Paper, but also in the reaction of member states to the social dialogue directives adopted in the late 1990s. There is case for saying that there this has been area of some considerable innovation in governance.

It was the Maastricht Treaty which established a role for 'social dialogue' between the peak-level federations representing trade unions and employers' associations in the formulation of EU-level labour standards. One possible option is for framework agreements between the 'social partners' to be given legal effect as directives; this is the route which resulted in the adoption of directives on parental leave, part-time work and fixed-term employment in the late 1990s. ${ }^{24}$ Another possibility is for the Community's regular law-making organs to act in a case where the social partners cannot reach a consensus on a framework agreement. This was the route eventually taken in the case of the directive on information and consultation of employees at national level which was adopted in 2002. ${ }^{25}$ A third possibility is for the social partners to reach an agreement which

23 'German companies flee to the UK', Financial Times, 24 June 2006.

24 Respectively, Directives 96/34, 97/81/EC and 99/70/EC.

25 Directive 2002/14/EC. 
has no independent legal force, and which they monitor and police; an agreement along these lines on employment conditions in tele-working was arrived at in $2004{ }^{26}$

Each of the directives just referred to sets out standards in the form of default provisions which can be adjusted through agreement between the social actors at sectoral, enterprise or plant level. It is therefore likely indeed, intended - that a variety of practices will result from the implementation of the directives. The impact, to date, of the three directives adopted in the late 1990s, suggests that this mode of governance can create act as a catalyst for mutual learning. These directives have a number of related goals, principal among which is the so-called 'normalisation' of so-called flexible forms of work (part-time and fixedterm employment). This implies some re-regulation, in the form of a requirement of equality treatment between part-time and fixed-term workers respectively and 'normal' full-time, indefinite-duration workers, and a degree of liberalisation, in the form of the removal of barriers to the adoption of flexible working arrangements. Encouragement for parents to share childcare responsibilities is a linked aspect of this policy.

The directives have had divergent effects, depending on the pre-existing state of the law in different member states (Mückenberger and Weinreich, 2006; Deakin, 2006). In Germany, the fixed-term employment directive has led to a de facto loosening of the conditions for this form of employment, which are now spelled out in legislation where before they were the result of case law. In Britain, by contrast, where no justification for departing from the 'norm' of an indefinite-duration contract of employment was previously needed, the directive has had the effect of requiring such a justification for the first time in a way which is having a substantial impact on employment practices in sectors reliant on fixedterm employment. In Germany the legislation implementing the part-time work directive went beyond what was necessary in enacting a right to work part-time where family circumstances justified it; in Britain, a more limited right to request flexible working was enacted as part of a wider process of legislating for 'work-life balance' issues, but legislation has continued to progress towards a more complete recognition of the right to

26 Social Partners' Framework Agreement on Teleworking, 16 July 2002. 
flexible working, as has the practice in certain sectors. Finally, the passage of the parental leave directive has triggered a debate in both countries about a system of leave-sharing between female and male parents, a system which is not required by the directive but around which a political consensus appears to be building, influenced by the example of existing practice in the Nordic member states. In short, convergence on a uniform set of legal instruments for regulating flexible work and the worklife balance is unlikely to be the end result of the process of implementation of these directives; however, that process has triggered a reassessment of policy which may lead in time to a reassessment of national practices in at least two member states whose laws were previously at opposite ends of the spectrum.

But as with company law, developments in labour law are increasingly overshadowed by the possibility that the Court will use its freedom of movement jurisprudence to mount a challenge to the autonomy of member states. Two high-profile cases in which the freedom of movement principle has recently run up against social policy considerations are Viking $^{27}$ and Laval. $^{28}$ Viking concerns the re-flagging of a Finnish passenger vessel under Estonian law in order to reduce labour costs associated with Finnish labour legislation and collective agreements, a move which was prevented by industrial action; Laval arises from industrial action taken by Swedish unions to force a Lithuanian building company, carrying out work in Sweden using workers who were Lithuanian nationals, to observe the terms of a local collective agreement. In Viking the legality of the industrial action was challenged on the grounds of its incompatibility with the principle of freedom of establishment (as in Centros), while in Laval the challenge mainly invoked the principle of freedom to supply services. At the time of writing, the Advocates General involved in the cases have each produced an opinion; ${ }^{29}$ it remains to be seen how the Court will finally resolve the

27 Viking Line ABP v. International Transport Workers' Federation [2006] 1 CMLR 27; see Davies, 2006.

28 Swedish Labour Court Decision 2005 No. 49; see Eklund, 2006.

29 See Case C-438/05 ITWF v. Viking Line ABP, opinion of Poiares Maduro AG, 23.5.2007; Case C-341/05 Laval un Partneri Ltd. v. Svenska Byggnadsarbetareförbundet, Judgment of Mengozzi AG, 23.5.2007. 
questions at stake. One possible outcome, which has been foreshadowed in the two opinions so far issued, is that the right to take industrial action will be found to subject to the free movement principle, and that it will be left up to national courts to strike a balance between the two according to the principle of proportionality. The application of a proportionality test makes future litigation more likely, whatever the result in these particular cases.

\section{ASSESSMENT}

The recent experience of company law presents a multi-faceted picture from the point of view of governance. Although there have been very substantial new initiatives in the company law field, prospects for the standardisation of company laws, which briefly resurfaced in the early 2000s in the context of deliberations over the Thirteenth Directive, have once again receded, in part as a result of the outcome of that process, which some have seen permitting an undesirable fragmentation of statelevel laws. The same outcome can however be understood as introducing a reflexive element into the application at member state level of the general principles now governing takeover bids. Fragments of an OMC for company law can also be identified, in the activities of the European Corporate Governance Forum. However, this currently falls far short of a full information exchange, nor is there any effective benchmarking or peer review, as yet.

More generally, the company law reform process demonstrates a fixation on a particular conception of best practice, which is represented by the principal-agent model of corporate governance, in particular as it is expressed in the 'global standard' set by the OECD principles and, to a large degree, by US and British practice. Diversity of practice at member state level is also being potentially undermined by the increased possibilities for corporate migration following the Centros case, and by the Commission's support for the principle of cross-border 'freedom of choice' in the matter of corporate governance forms. 
Labour law, despite the recent political log-jam on new regulatory measures such as the revisions to the Working Time Directive, represents a more hopeful case for methods of open coordination. The employment strategy OMC has dovetailed with the social dialogue directives of the late 1990s to stimulate a range of state-level responses to the Commission's demand for a better reconciliation of the goals of flexibility and protection. At the same time, the submerged tension between member state autonomy in the social policy field, and the integrationist tendencies of the legislation and case law relating to freedom of movement, has been cast into sharp relief by the Viking and Laval litigation.

This review of recent developments prompts the following reflections on the prospects for the OMC and for the wider case which has been made for deliberative polyarchy as a mode of governance.

Firstly, clarity would be assisted in current debates if there were a more explicit recognition that the OMC is not a radical break with the past but is the latest in a series of developments which have seen the emergence and application of reflexive modes of governance in the EU. The origins of reflexive governance go back to the early years of the Community and to developments in the 1980s and 1990s which the theory of deliberative polyarchy appears to have overlooked.

Secondly, as Charles Sabel and Jonathan Zeitlin rightly emphasise in their account of deliberative polyarchy, the 'informal' mechanisms of the OMC should be seen as complementary to the 'formal' ones associated with lawmaking via directives and court judgments. Effective interaction between the framework rules set by the $\mathrm{EU}$ and the responses of member states is most likely to occur when a combination of informal and formal mechanisms is present.

Thirdly, and relatedly, the most important choice facing the EU in terms of governance is not that between formality and informality. Labour law, rather than suffering from the effects of 'asymmetric regulation' or a lack of formally binding measures by comparison with company law since the turn of the century, has benefited from the flexibility offered by the OMC in combination with the social dialogue procedure for law making. Rather, the critical issue, which affects both company law and labour law, 
is how to resolve the tension between member state autonomy and the requirements of economic integration at EU level. Proponents of deliberative polyarchy claim that it enables market liberalization to proceed alongside the preservation and reconfiguration of national-level systems of social protection. This claim arguably understates the risks inherent in the appearance of a form of relatively unconstrained regulatory competition which, in the name of freedom of choice, has the potential to undermine national-level decision making. The problem here is not simply that the OMC, in particular, and deliberative polyarchy, more generally, provide a weak bulwark, at best, against the deployment of free movement jurisprudence and the logic of cross-border freedom of choice to impose a market integration test on state-level regulation. The learning model embedded in deliberative polyarchy is itself part of the problem. As the case of the company law OMC illustrates, the learning process which is at the core of the open method, while paying lip service to crossnational diversity, can degenerate into a mechanism for entrenching a single 'best model', against which the practices of the member states are subsequently benchmarked. This can be contrasted with learning models, such as those associated with the model of reflexive harmonization, which

are more clearly focused on the preservation of diversity as such. Claims for the OMC as a template for global governance should, for this reason, be very carefully scrutinized.

\section{REFERENCES}

Barnard, C and Deakin, S (2002) 'Market access and regulatory competition' in C. Barnard and J. Scott (eds.) The Law of the Single Market: Unpacking the Premises (Oxford: Hart).

Cohen, J and Sabel, C (1997) 'Directly-deliberative polyarchy' European Law Journal 3: 313-42.

Commission (2003) Modernising Company Law and Enhancing Corporate Governance in the European Union - A Plan to Move Forward. COM (2003) 584 final. 
Davies, A. (2006) 'The right to strike versus freedom of establishment in EU law: the battle commences’ Industrial Law Journal, 35; 76-86.

Deakin, S (1996) 'Labour law as market regulation: the economic foundations of European social policy', in Davies, P., Lyon-Caen, A., Sciarra, S. and Simitis, S. (eds.) Principles and Perspectives on EC Labour Law: Liber Amicorum for Lord Wedderburn, Oxford: Oxford University Press.

Deakin, S (1999) 'Two types of regulatory competition: competitive federalism versus reflexive harmonisation. A law and economics perspective on Centros' Cambridge Yearbook of European Legal Studies, 2: 231-260.

Deakin, S. (2001) 'Regulatory competition versus harmonisation in European company law', in D. Esty and D. Geradin (eds.) Regulatory Competition and Economic Integration: Comparative Perspectives (Oxford: OUP), 190-217.

Deakin, S. and Slinger, G. (1997) 'Hostile takeovers, corporate law and the theory of the firm' Journal of Law and Society, 24: 124-150.

Deakin, S. (2006) 'The capability approach and the implementation of directives on parental leave, part-time work and fixed-term employment in the UK', paper presented to the workshop on 'The Capability Approach and the Implementation of European Social Agreements and Directives', European Commission, Brussels, June 2006.

Deakin, S. (2007) 'Is the "modernization" of company law a threat to employee voice within the enterprise? A British perspective', in D. Sadowski and M. Weiss (eds.) [book on codetermination, forthcoming].

Eklund, E. (2006) ‘The Laval case’ Industrial Law Journal, 35: 202-8.

Gerstenberg, O. and Sabel, C. (2002) 'Directly-deliberative polyarchy: an institutional ideal for Europe?' in R. Dehousse and C. Joerges (eds.) Good Governance and Administration in Europe's Integrated Market. The Academy of European Law (EUI) Volume XI, Book 1, 289-341 (Oxford: Oxford University Press). 
High Level Group (2002a) Report of the High Level Group of Company Law Experts on Issues Related to Takeover Bids (Brussels: European Commission).

High Level Group (2002b) Report of the High Level Group of Company Law Experts on a Modern Regulatory Framework for Company Law in Europe (Brussels: European Commission).

Mückenberger, U. and Weinreich, I. (2006) 'Changes to German national legislation under the influence of European directives' paper presented to the workshop, 'The Capability Approach and the Implementation of European Social Directives’, WIKO, Berlin, May 2006.

Paqué, K.-H. (1997) 'Does Europe’s Common Market need a social dimension? Some academic thoughts on a popular theme', in J.T. Addison and W.S. Siebert (eds.) Labour Markets in Europe: Issues of Harmonisation and Regulation (London: Dryden)

Roe, M (2005) ‘Delaware’s politics’ Harvard Law Review 118: 2493-

Sabel, C. and Zeitlin, J. (2006) 'Learning from difference: the new architecture of experimentalist governance in the European Union'. Paper presented to the Theory of the Norm workshop, FP6 project 'Reflexive Governance in the Public Interest', Brussels, 27 October 2006.

Schmitthoff, C (1973) 'The future of the European company law scene', in C. Schmitthoff (ed.) The Harmonisation of European Company Law, London: UKNCCL.

Sugden, R (1997) 'Spontaneous order' in P. Newman, The New Palgrave Dictionary of Economics and the Law, London: Macmillan.

Takeover Panel (2005b) Explanatory Paper. Implementation of the European Directive on Takeover Bids (London: Takeover Panel). 
Takeover Panel (2006) The Implementation of the Takeovers Directive. Statement by the Panel and the Code Committee following the External Consultation Process on PCP 2005/5 (London: Takeover Panel).

Villiers, C (1998) European Company Law: Towards Democracy? (Aldershot: Dartmouth)

Weiler, P. (1990) Governing the Workplace: The Future of Labor and Employment Law (Cambridge, MA: Harvard University Press).

Zumbansen, P. (2006) 'Spaces and places: a systems theory approach to regulatory competition in European company law', European Law Journal, 12: 535-557. 